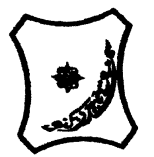

Bayero Journal of Pure and Applied Sciences, 11(2); 9 - 13

Received: April, 2018

Accepted: November, 2018

ISSN $2006-6996$

\title{
SYNTHESIS AND CHARACTERIZATION OF A SCHIFF BASE AND ITS METAL (II) COMPLEXES DERIVED FROM 2, 4-DINITROPHENYL HYDRAZINE AND 2, 4- DICHLOROBENZALDEHYDE
}

\author{
Nuraddeen, ${ }^{1}$ A. and Abubakar, ${ }^{1} \mathrm{M}$. \\ ${ }^{1}$ Department of Pure and Industrial Chemistry, Umaru Musa Yar'adua University, P.M.B 2218, Katsina \\ State, Nigeria. \\ Correspondence Author: nuraddeen.abdurrahman@umyu.edu.ng: 08069102465
}

\section{ABSTRACT}

A hydrazone Schiff base was synthesized by the reaction of 2, 4-dinitrophenyl and 2, 4dichlorobenzaldehyde in their ethanolic solutions. The corresponding metal (II) complexes of the synthesized Schiff base were obtained by refluxing the ethanolic solutions of $\mathrm{CoCl}_{2}, \mathrm{CuCl}_{2}, \mathrm{NiCl}_{2}$ and $\mathrm{ZnCl}{ }_{2}$ salts. The physical properties of the Schiff base and its corresponding metal (II) complexes were investigated. The melting point temperature of the Schiff base was $220^{\circ} \mathrm{C}$, while the decomposition temperatures of the complexes were $228^{\circ} \mathrm{C}, 225^{\circ} \mathrm{C}, 228^{\circ} \mathrm{C}$ and $226^{\circ} \mathrm{C}$ for Co(II), Cu(II), Ni(II) and Zn(II) complexes respectively. The Solubility test was also studied. The formation of the Schiff base and its metal (II) complexes were confirmed using FTIR spectroscopy. Both the Schiff base and its metal (II) complexes were found to be stable at room temperature. Some were found to be soluble in many organic solvents but all were insoluble in water. Key words; Schiff base, metal complexes, decomposition temperature, melting point

\section{INTRODUCTION}

For decades, the chemistry of metal complexes which has fascinated and inspired the chemists across the globe. There is an increasing academic, biochemical and commercial interest on the metal complexes of inorganic chelating ligands (Archana 2013; Bagihalli et al., 2008; Gwaram et al., 2012). This has brought the emergence of related fields like, organometallic chemistry, homogeneous catalysis and heterogeneous catalysis. Among the chelating ligands, Schiff base ligands have attracted the attention of many chemists due to their ease of preparation and complexation. From 1834-1915
Schiff bases, named after Hugo Schiff as the compounds having a formula $\mathrm{RHC}=\mathrm{NR}^{\prime}$ where $\mathrm{R}$ is an aryl group and $R^{\prime}$ is either an alkyl or aryl group (Layer, 1963). Schiff base ligands contained azomethine group $(-\mathrm{RC}=\mathrm{N}-)$ which are formed from the condensation of a primary amine with an active carbonyl compound in an organic solvent media. Schiff base metal complexes have been known since the middle of nineteenth century and even before the report of general preparation of the Schiff base ligands (Sebastian, 2010).<smiles>[R]C([R])=N[2H]</smiles>

Figure 1: General structure of Schiff base

Where $R^{1}=$ Aryl group, $R^{2}=$ Hydrogen and $R^{3}=$ Alkyl or aryl group<smiles>CC(=NCCN(C)C)c1ccccc1</smiles>

Where $\mathbf{R}=\mathbf{N}$ (Ligand two) and C-OH (Ligand one)

Figure 2: Structure of Schiff Base Derived from Acetyl Pyridine and Acetophenone Derivatives (Gwaram et al., 2012) 
BAJOPAS Volume 11 Number 2 December, 2018

The complexes of metallic salts are more potent and less toxic in many cases as compared to the parent drug (Gwaram et al; 2012). These metal complexes are found to be interesting due to their biological applications like, antibacterial, antifungal and anti-tumor activity. Schiff base compounds and their metal complexes have been widely investigated because of their wide range of applications including catalysis (Gupta \& Sutar, 2007). They are studied widely due to their synthetic flexibility, selectivity and sensitivity towards the central metal atom; structural similarities with natural biological compounds and also because there is presence of azomethine group $(-\mathrm{N}=\mathrm{CH}-)$ which is important in explaining the mechanism of transformation reaction biologically (Shargi \& Nasseri, 2003).

Many complexes are used as catalysts in synthesis of other compound, pharmaceuticals and many other areas in chemistry, biochemistry and material science as well as using them as the starting materials in the production of many compounds.

\section{Aim and Objectives}

The aim of this research is to prepare and characterize a hydrazone Schiff base and its metal (II) complexes using FTIR and melting point apparatus and to carried out solubility test The main objectives of this research are to:

1. Prepare the hydrazone Schiff base and its metal (II) complexes of $\mathrm{Cu}, \mathrm{Co}, \mathrm{Ni}$ and $\mathrm{Zn}$
2. Characterize the prepared Schiff base and its metal (II) complexes using FTIR and melting point apparatus

3. Determine the solubility potential of the prepared hydrazone Schiff base and its metal (II) in water and some organic solvents

\section{MATERIALS AND METHODS}

All the reagents and solvents purchased were of analytical grades and used as ordered without further purification.

$0.198 \mathrm{~g}$ of 2, 4-dinitrophenylhydrazine was accurately measured in a washed $250 \mathrm{ml}$ conical flask and dissolved with $15 \mathrm{ml}$ methanol. $1 \mathrm{ml}$ of concentrated $\mathrm{HCl}$ was added and a clear solution was formed upon continuous stirring for about 15 minutes.

$0.1740 \mathrm{~g}$ of 2, 4-chlorobenzaldehyde was accurately measured in a washed $250 \mathrm{ml}$ conical flasks and dissolved with $10 \mathrm{ml}$ methanol a cleared solution was obtained upon stirring for about 15 minutes.

\section{Synthesis of Schiff Base:}

The prepared solution of 2,4dinitrophenylhydrazine (1 $\mathrm{mmol})$ and 2,4dichlorobenzaldehyde $(1 \mathrm{mmol})$ were mixed together (figure 3 ) and refluxed for 1 hour, an orange yellow precipitate was obtained which was filtered, washed with methanol and dried in a dessiccator containing Phosphorus Pentaoxide for 3 hours.

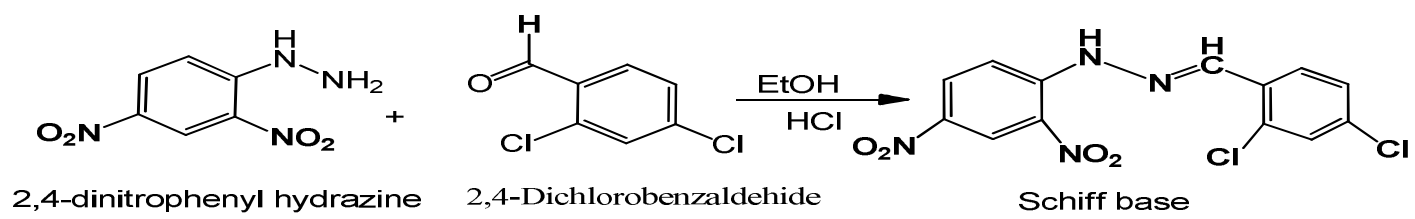

\section{Scheme 1: Preparation of Schiff base}

Synthesis of Schiff Base Metal Complexes: The complexes were synthesized in 1:1 molar ratio of metal: ligand. To a solution of the prepared Schiff base ligand $(0.2 \mathrm{~g}, 0.00056$ moles) in $15 \mathrm{ml}$ ethanol, an equimolar solution of $\mathrm{CoCl}_{2}(0.134 \mathrm{~g}, 0.00056$ moles$)$ in $10 \mathrm{ml}$ ethanol was added and the mixture was refluxed for 3 hours using a hot plate magnetic stirrer (figure 4). The product formed was allowed to cool at room temperature, filtered, washed with ethanol and stored in a dessiccator containing phosphorus Pentaoxide for 3 hours. Same procedure was repeated for $\mathrm{NiCl}_{2}, \mathrm{ZnCl}_{2}$ and $\mathrm{CuCl}_{2}$.<smiles>O=[N+]([O-])c1ccc(N/N=C/c2ccc(Cl)cc2Cl)c([N+](=O)[O-])c1</smiles>

Scheme 2: Preparation of metal complexes Where M = Cu (II), Co (II), Ni (II) and Zn (II) 
BAJOPAS Volume 11 Number 2 December, 2018

The melting point/decomposition temperature for the Schiff base and its corresponding metal (II) complexes were determined using melting point apparatus SMP1. The FTIR spectra of the prepared Schiff base and its corresponding metal (II) complexes were carried out $4000-400 \mathrm{~cm}^{-1}$ range.

\section{RESULTS AND DISCUSSION}

The results in Table 1 indicate that the Schiff base and its corresponding metal (II) complexes are colored. The color orange yellow is for the Schiff base as reported earlier (Archana, et al., 2013 and Hassan, et al; 2006) while dirty green, pale blue, green and yellow colors are for Co(II),
$\mathrm{Cu}(\mathrm{II}), \mathrm{Ni}(\mathrm{II})$ and $\mathrm{Zn}(\mathrm{II})$ complexes respectively. The change in color of the Schiff base from yellow to dirty green, pale blue, green and yellow was due to complexation which resulted into the formation of coordination compounds. The melting point/decomposition temperature for the Schiff base and its corresponding metal (II) complexes range between $220^{\circ} \mathrm{C}-225^{\circ} \mathrm{C}$ (Table 1 ). The results showed some similarities in physical properties of both Schiff base and its corresponding metal (II) complexes. There were similarities with a report by Mustapha et al., 2009 and it indicated the high stability of the compounds.

Table 1: Physical properties of Schiff base and its Metal (II) Complexes

\begin{tabular}{|c|c|c|c|c|}
\hline Compound & Molecular formula & Colour & $\begin{array}{c}\text { Decomposition } \\
\text { Temp. }\left({ }^{\circ} \mathrm{C}\right)\end{array}$ & $\mathrm{MP}\left({ }^{\circ} \mathrm{C}\right)$ \\
\hline Schiff base & {$\left[\mathrm{C}_{13} \mathrm{H}_{8} \mathrm{Cl}_{2} \mathrm{~N}_{4} \mathrm{O}_{4}\right]$} & $\begin{array}{l}\text { Orange } \\
\text { yellow }\end{array}$ & & 220 \\
\hline Co (II) complex & $\mathrm{Co}\left[\left(\mathrm{C}_{13} \mathrm{H}_{8} \mathrm{Cl}_{2} \mathrm{~N}_{4} \mathrm{O}_{4}\right) \mathrm{Cl}_{2}\right]$ & $\begin{array}{l}\text { Dirty } \\
\text { green }\end{array}$ & 228 & \\
\hline Cu (II) complex & $\mathrm{Cu}\left[\left(\mathrm{C}_{13} \mathrm{H}_{8} \mathrm{Cl}_{2} \mathrm{~N}_{4} \mathrm{O}_{4}\right) \mathrm{Cl}_{2}\right]$ & $\begin{array}{l}\text { Pale } \\
\text { blue }\end{array}$ & 225 & \\
\hline $\mathrm{Ni}$ (II) complex & $\mathrm{Ni}\left[\left(\mathrm{C}_{13} \mathrm{H}_{8} \mathrm{Cl}_{2} \mathrm{~N}_{4} \mathrm{O}_{4}\right) \mathrm{Cl}_{2}\right]$ & Green & 228 & \\
\hline Zn (II) complex & $\mathrm{Zn}\left[\left(\mathrm{C}_{13} \mathrm{H}_{8} \mathrm{Cl}_{2} \mathrm{~N}_{4} \mathrm{O}_{4}\right) \mathrm{Cl}_{2}\right]$ & Yellow & 226 & \\
\hline
\end{tabular}

The FTIR results were reported in Table 2 below and showed a band appeared at 3287.17 $\mathrm{cm}^{-1}$ assigned to $\mathrm{u}(\mathrm{N}-\mathrm{H})$ vibration frequency for the free ligand which was closer to the $3450 \mathrm{~cm}^{-1}$ and 3455- 3297 obtained by Riswan, et al 2014 .The appearance of absorption band at the region of $1614.60 \mathrm{~cm}^{-1}$ assigned to $\mathrm{U}$ $(\mathrm{C}=\mathrm{N})$ stretching vibration which is an important feature of Schiff base and it was supported by the literature (Hassan et at., 2006, Imtiyaz, et al.,2015). Absorption band also appeared in the free ligand at $3095.70 \mathrm{~cm}^{-1}$ can be assigned to $u(\mathrm{C}-\mathrm{H})$ stretching vibration and is within the range of $3100-3000 \mathrm{~cm}^{-1}$ for $\mathrm{C}-\mathrm{H}$ aromatic. A weak absorption band appeared at $590.34 \mathrm{~cm}^{-1}$ can be assigned to $\mathrm{U}(\mathrm{C}-\mathrm{Cl})$ because it was within the range of $590-700 \mathrm{~cm}^{-1}$ (Kazuo
Nakamoto., 2009). In the ligand characteristic frequencies appeared at the region of $1514.29 \mathrm{~cm}^{-1}$ was assignable to $\mathrm{U}\left(\mathrm{C}-\mathrm{NO}_{2}\right)$ stretching vibration and they were within the range of $1555-1485 \mathrm{~cm}^{-1}$ (Kazuo ,2009).

In all the metal (II) complexes, there were a little shift in $\mathrm{U}(\mathrm{C}=\mathrm{N})$ from 1614.60 to $1615.90-1614.80 \mathrm{~cm}^{-1}$ this indicate the stretching vibration of the azomethine groups and possible formation of the complexes (Yustina, 2009). The appearance of weak absorption bands in all the metal complexes at the range of $562.33-557.15 \mathrm{~cm}^{-1}$ can be attributed to the stretching vibration of Metal Nitrogen $(\mathrm{M}-\mathrm{N})$ and it was similar to what was confirmed in the literatures (Deoghoria, 2004 Bagihalli,2008 and Shahabadi,2010)

Table 2: The Infrared Spectral Data Schiff base and its Metal (II) Complexes.

\begin{tabular}{|c|c|c|c|c|c|c|}
\hline Molecular formula & $\begin{array}{l}\mathrm{UC}-\mathrm{NO}_{2} \\
\left(\mathrm{~cm}^{-1}\right)\end{array}$ & $\begin{array}{c}\text { UN-H } \\
\left(\mathrm{cm}^{-1}\right)\end{array}$ & $\begin{array}{l}\text { U C =N } \\
\left(\mathrm{cm}^{-1}\right)\end{array}$ & $\begin{array}{l}\text { UM-N } \\
\left(\mathrm{cm}^{-1}\right)\end{array}$ & $\begin{array}{c}\text { uC-Cl } \\
\left(\mathrm{cm}^{-1}\right)\end{array}$ & $\begin{array}{l}\mathrm{uC}-\mathrm{H} \\
\left(\mathrm{cm}^{-1}\right)\end{array}$ \\
\hline$\left[\mathrm{C}_{13} \mathrm{H}_{8} \mathrm{Cl}_{2} \mathrm{~N}_{4} \mathrm{O}_{4}\right]$ & 1514.29 & 3287.17 & 1614.6 & - & 590.34 & 3095.7 \\
\hline $\mathrm{Co}\left[\left(\mathrm{C}_{13} \mathrm{H}_{8} \mathrm{Cl}_{2} \mathrm{~N}_{4} \mathrm{O}_{4}\right) \mathrm{Cl}_{2}\right]$ & 1534.31 & 3286.56 & 1615.21 & 562.13 & 587.67 & 3094.79 \\
\hline $\mathrm{Cu}\left[\left(\mathrm{C} 13 \mathrm{H} 8 \mathrm{Cl} 2 \mathrm{~N}_{4} \mathrm{O}_{4}\right) \mathrm{Cl}_{2}\right]$ & 1515.63 & 3280.71 & 1614.8 & 558.42 & 604.5 & 3095.79 \\
\hline $\mathrm{Ni}\left[\left(\mathrm{C} 13 \mathrm{H} 8 \mathrm{Cl} 2 \mathrm{~N}_{4} \mathrm{O}_{4}\right) \mathrm{Cl}_{2}\right]$ & 1513.94 & 3286.58 & 1615.61 & 562.33 & 592.15 & 3094.68 \\
\hline $\mathrm{Zn}\left[\left(\mathrm{C}_{13} \mathrm{H}_{8} \mathrm{Cl}_{2} \mathrm{~N}_{4} \mathrm{O}_{4}\right) \mathrm{Cl}_{2}\right]$ & 1513.72 & 3286.82 & 1615.90 & 557.15 & 592.31 & 3094.75 \\
\hline
\end{tabular}


BAJOPAS Volume 11 Number 2 December, 2018

The solubility test (table 3 ) was also carried out and the results obtained from the Schiff base and its corresponding metal (II) complexes were almost similar. The Schiff base and its metal complexes were found to be insoluble in water but soluble in hot methanol and ethanol.
However, the ligand and their metal (II) complexes were soluble in different organic solvents (DMSO, acetone, chloroform, ethyl acetate and $\mathrm{CCl}_{4}$ ) except in diethyl ether and nhexane this was due to the covalent nature of the of the compounds (Stephen et al.,1963)

Table 3: Solubility Test for Schiff base and its Corresponding Metal (II) Complexes

\begin{tabular}{|c|c|c|c|c|c|c|c|c|c|c|}
\hline Molecular formula & $\frac{\bar{d}}{\stackrel{ \pm}{\pi}}$ & 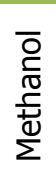 & $\begin{array}{l}\overline{0} \\
\substack{0 \\
\mathbb{0}} \\
\text { 吉 }\end{array}$ & $\sum_{0}^{\mathrm{N}}$ & 竞 & $\begin{array}{l}E \\
\text { 흠 } \\
\text { 임 } \\
\text { 은 }\end{array}$ & 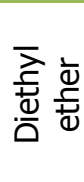 & 全莣 & U্ত & 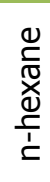 \\
\hline $\begin{array}{l}{\left[\mathrm{C}_{13} \mathrm{H}_{8} \mathrm{Cl}_{2} \mathrm{~N}_{4} \mathrm{O}_{4}\right]} \\
\mathrm{Co}\left[\left(\mathrm{C}_{13} \mathrm{H}_{8} \mathrm{Cl}_{2} \mathrm{~N}_{4} \mathrm{O}_{4}\right) \mathrm{Cl}_{2}\right] \\
\mathrm{Cu}\left[\left(\mathrm{C}_{13} \mathrm{H}_{8} \mathrm{Cl}_{2} \mathrm{~N}_{4} \mathrm{O}_{4}\right) \mathrm{Cl}_{2}\right]\end{array}$ & $\begin{array}{l}\text { IS } \\
\text { IS } \\
\text { IS }\end{array}$ & $\begin{array}{l}\text { SH } \\
\text { SH } \\
\text { SH }\end{array}$ & $\begin{array}{l}\text { SH } \\
\text { SH } \\
\text { SH }\end{array}$ & $\begin{array}{l}\mathrm{S} \\
\mathrm{S} \\
\mathrm{S}\end{array}$ & $\begin{array}{l}S \\
S \\
S\end{array}$ & $\begin{array}{l}S \\
S \\
S\end{array}$ & $\begin{array}{l}\text { SS } \\
\text { IS } \\
\text { IS }\end{array}$ & $\begin{array}{l}S \\
S \\
S\end{array}$ & $\begin{array}{l}\mathrm{S} \\
\mathrm{S} \\
\mathrm{S}\end{array}$ & $\begin{array}{l}\text { SS } \\
\text { IS } \\
\text { IS }\end{array}$ \\
\hline $\begin{array}{l}\mathrm{Ni}\left[\left(\mathrm{C}_{13} \mathrm{H}_{8} \mathrm{Cl}_{2} \mathrm{~N}_{4} \mathrm{O}_{4}\right) \mathrm{Cl}_{2}\right] \\
\mathrm{Zn}\left[\left(\mathrm{C}_{13} \mathrm{H}_{8} \mathrm{Cl}_{2} \mathrm{~N}_{4} \mathrm{O}_{4}\right) \mathrm{Cl}_{2}\right]\end{array}$ & $\begin{array}{l}\text { IS } \\
\text { IS }\end{array}$ & $\begin{array}{l}\mathrm{SH} \\
\mathrm{SH}\end{array}$ & $\begin{array}{l}\mathrm{SH} \\
\mathrm{SH}\end{array}$ & $\begin{array}{l}\mathrm{S} \\
\mathrm{S}\end{array}$ & $\begin{array}{l}S \\
S\end{array}$ & $\begin{array}{l}S \\
S\end{array}$ & $\begin{array}{l}\text { IS } \\
\text { IS }\end{array}$ & $\begin{array}{l}S \\
S\end{array}$ & $\begin{array}{l}S \\
S\end{array}$ & $\begin{array}{l}\text { IS } \\
\text { IS }\end{array}$ \\
\hline
\end{tabular}

Key: $\mathrm{S}=$ Soluble, $\mathrm{SS}=$ Slightly Soluble, $\mathrm{IS}=$ Insoluble, $\mathrm{SH}=$ Soluble in Hot

\section{CONCLUSION}

Based on the results obtained, it can be concluded that 2, 4-dinitrophenyl hydrazine and 2, 4-dichlorobenzaldehyde were successfully used as the starting materials for the preparation of Schiff base and its metal (II)

\section{REFERENCES}

Archana S. (2013): Synthesis and characterization of Schiff base derived from salicylaldehyde and thiohydrazones and its metal complexes. Advances in Applied Science Research: 152-154

Bagihalli, G.B. and Avaji, P.G. (2008): Synthesis, spectral characterization, in vitro antibacterial, antifungal and cytotoxic activities of $\mathrm{Co}$ (II), $\mathrm{Ni}(\mathrm{II})$ and $\mathrm{Cu}(\mathrm{II})$ complexes with 1,2,4-triazole

Schiff bases .European Journal of Medicinal Chemistry. 2639-2649

Deoghoria, S., Mustafa, G., Lu, T.H. and Chandra, S.K. (2004): Synthesis, characterization and X-ray crystal structure of copper (II) complexes with unsymmetrical tetradentate Schiff base ligands: first evidence of $\mathrm{Cu}$ (II) catalyzed rearrangement of unsymmetrical to symmetrical complex. Indian Journal of Chemistry: 329-332

Gupta, K. C. and Sutar, A. K. (2008): Catalytic Activities of Schiff Base Transition Metal Complexes. Coordination chemistry Reviews. $1420-1450$.

Gwaram, N.S., Ali H. M., Khalid H. (2012): Synthesis, characterization and biological application of some 2- complexes. The characterization of the prepared Schiff base and its metal (II) complexes were also studied. The characterization and analysis carried out substantially proved the formation of the metal (II) complexes of copper, nickel, cobalt and zinc.

acetylpyridine and acetophenone derivatives. Journal of Applied Pharmaceutical Science: 27-38

Hassan, H. M. Omid, P. and Christoph J. (2006): Synthesis and Spectral Characterization of Hydrazone Schiff Bases Derived from 2, 4-Dinitrophenylhydrazine and Crystal Structure of Salicylaldehyde-2, 4Dinitrophenylhydrazone. Naturforsch: 717- 720

Imtiyaz, R. P. and Athar A. H. (2015): Synthesis of Schiff Base Complexes of Mn (II) and Co (II) and their Catalytic Oxidation towards Olefins and Alcohols. Canadian Chemical transaction: 65-71

Kazuo Nakamoto, (2009): Infrared and Raman Spectra of Inorganic and Coordination Compounds, application in Coordination, Organometallic and Bioinorganic Chemistry. WileyInterscience. 408.

Layer, R. W. (1963): The Chemistry of Imines. Chemistry Review (Washington DC, UK) : 489-510

Mustapha, A., Reglinski, J. and Kennedy, A.R. (2009): The use of Hydrogenated Schiff Base ligands in the synthesis of Multimetallic compounds. Inorganic Chemistry Acta: 1267-1274 
BAJOPAS Volume 11 Number 2 December, 2018

Sebastian, M. (2010): Transition Metal Complexes of Quinoxaline based Schiff base Ligands: Synthesis, Characterization and Catalytic Study, Unpublished Ph.D Thesis. Submitted to the Department of Applied Chemistry, Cochin University of Science and Technology, 1-38.

Shahabadi, N.; Kashanian, S. (2010): DNA binding and DNA cleavage studies of a water soluble cobalt (II) complex contains dinitrogen Schiff base ligand: The effect of metal on the mode of binding. European Journal Medicinal Chemistry: $4239-4245$

Sharghi, H. and Nasseri, M. A. (2003): SchiffBase Metal (II) Complexes as New
Catalysts in the Efficient, Mild and Regioselective Conversion of 1, 2Epoxyethanes to 2- Hydroxyethyl Thiocyanates with Ammonium Thiocyanate.Bull. Chemical Society Japan.:137-142.

Stephen, H. and Stephen T. (1963): Solubility of organic and inorganic compounds. Macmillan, New York :1-79

Yustina, J., Puvaneswary,S, S,S, S., Ali, H.M., Robinson W.T. (2009): Synthesis and Characterization of some hydrazone Schiff base and their Cu (II) complexes. International Journal of Organic Chemistry: 3050-3054 